\title{
Relative susceptibility of different male-sterile cytoplasms in sorghum to shoot fly, Atherigona soccata
}

\author{
M.K. Dhillon ${ }^{1,2}$, H.C. Sharma ${ }^{1, *}$, B.V.S. Reddy ${ }^{1}$, Ram Singh $^{2}$, J.S. Naresh ${ }^{2} \&$ Zhu Kai ${ }^{3}$ \\ ${ }^{1}$ International Crops Research Institute for the Semi-Arid Tropics (ICRISAT), Patancheru 502 324, India; \\ ${ }^{2}$ Chaudhary Charan Singh Haryana Agricultural University, Hisar 125 004, India; ${ }^{3}$ Sorghum Research Institute, \\ Liaoning Academy of Agricultural Sciences, Shenyang, Liaoning, China \\ (*author for correspondence: e-mail: h.sharma@cgiar.org)
}

Received 21 January 2005; accepted 12 May 2005

Key words: Atherigona soccata, cytoplasmic male-sterility, mechanisms of resistance, shoot fly, sorghum, susceptibility

\section{Summary}

The shoot fly, Atherigona soccata is an important pest of sorghum, and host plant resistance is one of the most effective components for managing this pest. Most of the hybrids grown in India based on milo cytoplasm $\left(\mathrm{A}_{1}\right.$ cytoplasm) are highly susceptible to shoot fly. Therefore, the present studies were undertaken to evaluate different male-sterile cytoplasms (CMS) for their relative susceptibility to sorghum shoot fly. Oviposition and deadheart formation were significantly lower on the maintainer lines as compared to the corresponding male-sterile lines. Among the cytoplasms tested, $\mathrm{A}_{4} \mathrm{M}$ cytoplasm showed antixenosis for oviposition and suffered lower deadheart formation than the other cytoplasms tested. The $\mathrm{A}_{4} \mathrm{G}_{1}$ and $\mathrm{A}_{4} \mathrm{M}$ cytoplasms suffered lower deadhearts in tillers than the other cytoplasms. Recovery following shoot fly damage in $\mathrm{A}_{4} \mathrm{M}, \mathrm{A}_{3}$, and $\mathrm{A}_{2}$ cytoplasms was better than in the other cytoplasms tested. The larval and pupal periods were longer and male and female pupal weights lower in $\mathrm{A}_{4} \mathrm{M}$ and $\mathrm{A}_{4} \mathrm{VzM}$ CMS backgrounds compared to the other CMS systems. Fecundity and antibiosis indices on CMS lines were lower than on the B-lines. The $\mathrm{A}_{4} \mathrm{M}$ cytoplasm was found to be relatively resistant to sorghum shoot fly, and can be exploited for developing shoot fly-resistant hybrids for sustainable crop production in future.

\section{Introduction}

Sorghum (Sorghum bicolor (L.) Moench) is one of the most important cereal crops in the semi-arid tropics (SAT). It is grown widely in Asia, Africa, Australia, Americas, and the Mediterranean Europe (FAO, 2002). Insect pests are one of the major constraints for increasing production and productivity of sorghum, and cause a loss of over $\$ 1$ billion in the SAT. More than 150 species of insects have been recorded as pests of sorghum, of which sorghum shoot fly, Atherigona soccata (Rondani) (Diptera: Muscidae) is an important pest in Asia, Africa, and the Mediterranean Europe. Shoot fly larvae damage the growing point of 5-30 days old sorghum seedlings. As a result, the central leaf dries up, resulting in typical deadheart symptoms (Deeming, 1971; Pont, 1972). The larvae feed on the decaying tissue of the central leaf and pupate in the soil. As a result of deadheart formation, the main shoot is killed, and the plant may produce axial tillers if sufficient moisture and nutrients are available. The axial tillers serve as a mechanism of recovery resistance if they remain undamaged, but if shoot fly infestation continues, the seedling may die or presents a rossette appearance and fails to produce any grain. The levels of shoot fly infestation in sorghum may reach as high as $90 \%$ under delayed sowings (Hiremath \& Renukarya, 1966; Rao \& Gowda, 1967). 
Cultural practices, natural enemies, host plant resistance, and chemical control can be used for minimizing losses due to shoot fly. Host plant resistance is most relevant under subsistence farming conditions, as it involves no extra cost to the farmers. Plant resistance to sorghum shoot fly appears to be complex, and depends on the interplay of componential characters, which finally sum up in the expression of resistance to this pest. Therefore, it is important to identify sources and understand mechanisms responsible for sorghum resistance to shoot fly. Since most of the area under improved cultivars is planted with high-yielding hybrids, it is important to transfer genes conferring resistance to shoot fly into cytoplasmic male-sterile (A-lines), maintainer (B-lines) and restorer (R-lines) lines to develop high yielding hybrids with resistance to this pest (Dhillon, 2004). Effective use of cytoplasmic male-sterility has made it easier to incorporate the desired characters into hybrid parents (House, 1985) to increase crop productivity. Large-scale deployment of hybrids based on a single source of male-sterility is a potential danger to crop production, because of their possible susceptibility to insect pests and diseases. Therefore, it is important to deploy different CMS systems to develop strategies for producing cultivars with resistance to target insect pests and diseases. Most of the hybrids grown in India are based on milo cytoplasm ( $\mathrm{A}_{1}$ cytoplasm), which has been reported to be highly susceptible to insect pests (Sharma, 2001; Sharma et al., 2003, 2004). Alternative cytoplasmic male-sterility systems can be exploited to avoid insectpest outbreaks that might be related to the use of single source of cytoplasm by adding nuclear diversity in new parental combinations, which is not possible with the milo kafir cytoplasmic system (Schertz \& Pring, 1982). In addition to the milo-cytoplasm ( $\mathrm{A}_{1}$-cytoplasm), cytoplasmic male-sterile lines are also available in $\mathrm{A}_{2}$, $\mathrm{A}_{3}, \mathrm{~A}_{4}, \mathrm{~A}_{4} \mathrm{M}, \mathrm{A}_{4} \mathrm{VzM}$, and $\mathrm{A}_{4} \mathrm{G}_{1}, \mathrm{~A}_{5}, \mathrm{~A}_{6}, 9 \mathrm{E}$, and KS cytoplasmic backgrounds (Nagur, 1971; Schertz et al., 1989, 1997; Xu et al., 1998). However, the heterotic potential of these alternate cytoplasms has not been exploited due to lack of appropriate restorer lines. Efforts are under way to diversify the cytoplasmic male-sterility systems for hybrid production (Reddy \& Rao, 1998). Therefore, present studies were aimed at identifying alternate male-sterile cytoplasms with less susceptibility to shoot fly than milo, and gain an understanding of the components (antixenosis for oviposition, antibiosis, and recovery resistance) that contribute to resistance or susceptibility to sorghum shoot fly.

\section{Materials and methods}

The experiments were conducted under field and greenhouse conditions at the International Crops Research Institute for the Semi-Arid Tropics, Patancheru, Andhra Pradesh, India, between 2002 and 2003. The experimental material consisted of six isogenic lines in six male-sterile cytoplasmic backgrounds and their maintainer (B-lines) lines.

\section{Evaluation of different cytoplasms for resistance to shoot fly, Atherigona soccata, under field conditions}

The test material was planted in four row plots, $2 \mathrm{~m}$ long, and the rows were $75 \mathrm{~cm}$ apart. The test material was planted in a randomized complete block design (RCBD) along with shoot fly-resistant (IS 18551) and susceptible (Swarna) checks during the 2002 and 2003 rainy (last week of July) and 2003 late post-rainy (midOctober) seasons. There were three replications. The seed was planted with a four-cone planter at $5 \mathrm{~cm}$ below the soil surface under optimum moisture conditions, and the field was irrigated immediately after planting. The plants were thinned at 7 days after seedling emergence (DAE) to maintain a spacing of $10 \mathrm{~cm}$ between plants. The optimum levels of shoot fly infestations were maintained by manipulating the sowing dates and through the use of interlard fish-meal technique (Sharma et al., 1992). Normal agronomic practices were followed for raising the crop. No insecticide was applied in the crop during the vegetative phase. Data were recorded on oviposition (14 and 21 DAE) and deadheart formation (14, 21 and 28 DAE) due to shoot fly damage, tillers with deadhearts (28 DAE), and recovery resistance (at crop maturity) in the central two rows. Recovery resistance was assessed on a scale of 1 to 9 ( $1=$ most of the damaged plants with $2-3$ uniform tillers with panicles similar to the main plant, and $9=$ $<10 \%$ plants with uniform tillers with productive panicles). Production of axial tillers following damage to the main plant serves as a mechanism of recovery resistance in sorghum. These axial tillers, if not damaged by the shoot fly, produce a reasonable grain yield.

\section{Evaluation of different CMS and maintainer lines for resistance to sorghum shoot fly, Atherigona soccata, under greenhouse conditions}

\section{Insect culture}

The shoot fly females were collected from the fish-meal baited traps in the field. The traps were kept in fields 
having a sorghum crop at the seedling stage. A plastic jar filled with moist fish-meal was kept inside the trap (Sharma et al., 1992). The fish-meal was replaced every 4 days. The shoot flies were collected in the morning between 07:30 and 08:30 hours, and released in a wiremesh screened cage $(30 \mathrm{~cm} \times 30 \mathrm{~cm} \times 30 \mathrm{~cm})$. The females of $A$. soccata were separated from other flies, and released in a separate cage for further use. The females were provided with $20 \%$ sucrose solution on a cotton swab, and a mixture of brewer's yeast and glucose (1:1) in a petri dish. The sucrose solution was changed daily, while the yeast-glucose mixture was changed every 3 days.

\section{Antixenosis}

Antixenosis (non-preference) for oviposition was studied using a cage technique (Dhillon, 2004). Oviposition non-preference and deadheart formation in different CMS and maintainer lines were studied under dualchoice conditions. Each tray had two rows of CMS and two rows of the respective maintainer line. Under multi-choice conditions, each isogenic line in different CMS backgrounds along with its maintainer line were planted in a single tray $(40 \mathrm{~cm} \times 30 \mathrm{~cm} \times 14 \mathrm{~cm})$. For antibiosis studies, only one genotype was planted in a tray (no-choice conditions). There were six replications in a completely randomized design (CRD). The test material was exposed to 12 gravid shoot fly females per 40 plants at 9 DAE (at the fifth leaf stage) for $24 \mathrm{~h}$. After $24 \mathrm{~h}$, the shoot fly females were removed from the confinement cages, and data were recorded on the number of plants with eggs. Five days after infestation (14 DAE), data were also recorded on the number of plants with deadhearts. Data were expressed as percentage of plants with eggs or deadhearts.

\section{Antibiosis}

The appearance of deadhearts under no-choice conditions was monitored at $12 \mathrm{~h}$ intervals. The plants with deadhearts were labeled for date of deadheart appearance. Four days after deadheart formation, 15 deadhearts of same age were uprooted and placed in glass vials (20 ml capacity) individually; and observations were recorded on larval and pupal periods and survival, pupal weight, adult emergence, and fecundity. There were three replications in a completely randomized design. The deadhearts collected in glass vials were observed daily after 6 days of deadheart formation to record time to pupation. The days from deadheart appearance to pupation plus one day (because it takes one day for deadheart formation after egg hatching) was recorded as larval period. The larval period was recorded separately for each larva, and the mean larval period per replication was calculated for the surviving larvae (of 15 larvae under observation). The number of larvae that survived were also recorded, and expressed as a percentage of the total number of larvae under observation. The pupal period was recorded separately for each insect and the mean pupal period per replication was calculated for the surviving pupae. Pupal weight (mg) was measured for male and female pupae separately on an electronic balance within $24 \mathrm{~h}$ of pupation. After weighing, the pupae were placed in glass vials on moist sand to prevent water loss and pupal mortality because of desiccation. Mortality during pupal stage was estimated as: number of larvae survived - number of adults emerged $\times 100$. The number of adults emerged (from 15 insects under observation) were recorded, and expressed as percentage adult emergence. For fecundity studies, five pairs from each replication (for CMS or maintainer line) were released in wire-framed cages (30 $\mathrm{cm}$ diameter, $30 \mathrm{~cm}$ high) covered with nylon bags (60 mesh). The adults were provided with $20 \%$ sucrose solution in a cotton swab, and brewer's yeast + glucose $(1: 1)$ in a petri dish. Ten sorghum seedlings raised in plastic pots $(10 \mathrm{~cm}$ dia.) of the same genotype were provided to the shoot flies on alternate days for oviposition. Data were recorded on number of eggs laid. Data on different biological parameters were used for computing various indices as follows (Dhillon, 2004).

1. Development index $=$ Post-embryonic development period on the test genotype/Post-embryonic development period on the susceptible check (Prasad \& Bhattacharaya, 1975).

2. Weight index $=$ Pupal weight on the test genotype/Pupal weight on susceptible check (Deshmukh et al., 1977).

3. Adult emergence index $=$ Adult emergence on the test genotype (\%)/Adult emergence on the susceptible check (\%) (Tripathi et al., 1982).

4. Howe's growth index $=\log$ adult emergence $(\%) /$ Mean developmental period on a test genotype (Howe, 1971).

5. Fecundity index $=$ Number of eggs laid by the insects reared on the test genotype/Number of eggs laid by the insects reared on the susceptible check (Saxena, 1969).

6. Antibiosis index $=$ Development index + Weight index + Adult emergence index + Howe's growth index + Fecundity index. 


\section{Data analysis}

Data were subjected to analysis of variance to test the significance of differences among genotypes tested based on $F$-test at $P=0.05$. Standard error of means (S.E.) was used to test the significance of differences between cytoplasms. For the dual-choice tests, paired $t$-test was used to test the significance of differences at $P=0.05$.

\section{Results}

\section{Antixenosis for oviposition and deadheart formation}

\section{Multi-choice conditions}

The oviposition preference and percentage deadhearts in plants of different CMS and their maintainer lines were greater during the rainy season than in the crop sown during the post-rainy season. Deadheart formation in different cytoplasms ranged from 69.9 to $88.7 \%$, 87.4 to $97.5 \%$ and 92.3 to $99.0 \%$ at 14,21 and 28

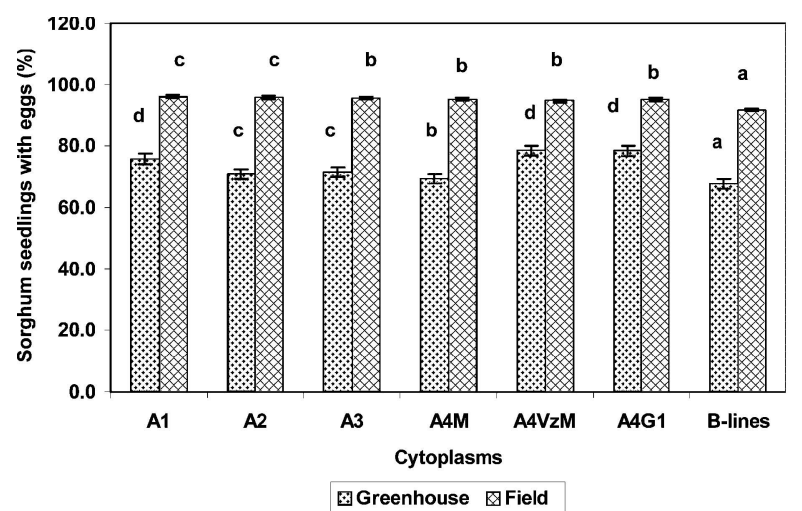

(A)

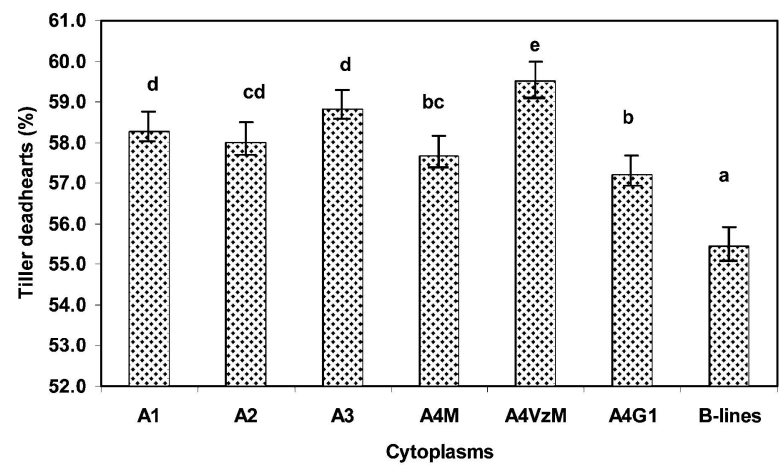

(C)
DAE, respectively (Table 1). The CMS lines had more deadhearts compared to the maintainer lines at 14 DAE (72.9-88.7\% versus 69.9-82.3\%), 21 DAE (89.897.5\% versus $87.4-96.0 \%)$ and 28 DAE (93.6-99.0\% versus $92.3-97.2 \%)$. ICSA 11 and ICSA 17 had significantly more deadhearts than the other isogenic lines tested at 14 and 21 DAE across cytoplasms. Least deadhearts were recorded on ICSA 26 and ICSA 88004. The oviposition and deadhearts were significantly lower on the maintainer lines as compared to the CMS lines. Among the cytoplasms tested, $\mathrm{A}_{4} \mathrm{M}$ was comparatively less preferred for oviposition and had lower deadheart incidence than the other cytoplasms tested (Figures 1A and $1 \mathrm{~B})$.

\section{Dual-choice tests}

Under dual-choice conditions in the greenhouse, there were $52.5-100.0 \%$ plants with eggs and $49.7-100.0 \%$ plants with deadhearts on the CMS lines; while on the maintainers, there were $66.4-100.0 \%$ plants with eggs and 50.9-95.0\% plants with deadhearts (Table 2). Plants of ICSA 17 in $A_{3}$ and $A_{4} G_{1}$, and ICSA 26 in

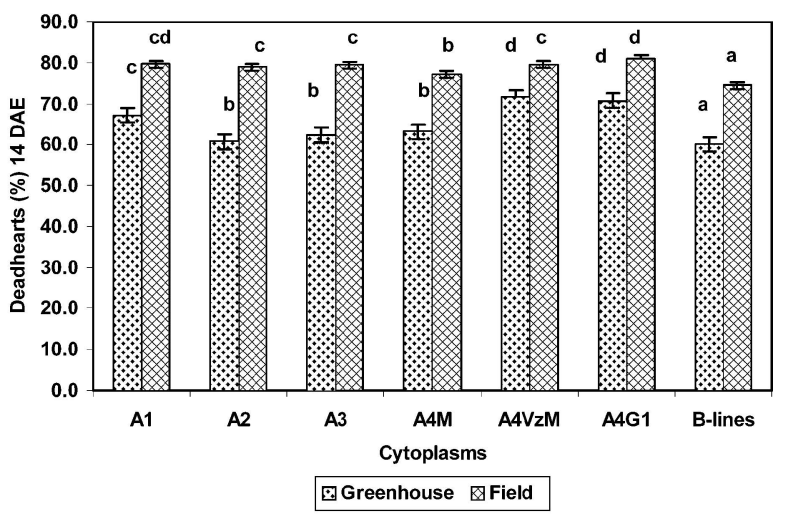

(B)

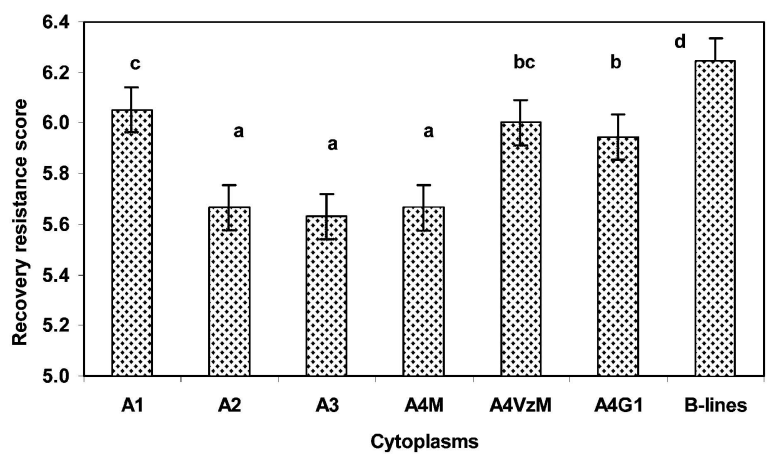

(D)

Figure 1. Oviposition (A), main plant deadhearts (B), and tiller deadhearts (C) by sorghum shoot fly, and recovery resistance (D) in different cytoplasmic male-sterile systems of sorghum. Bars with the same letter are not significantly different at $P=0.05$. 


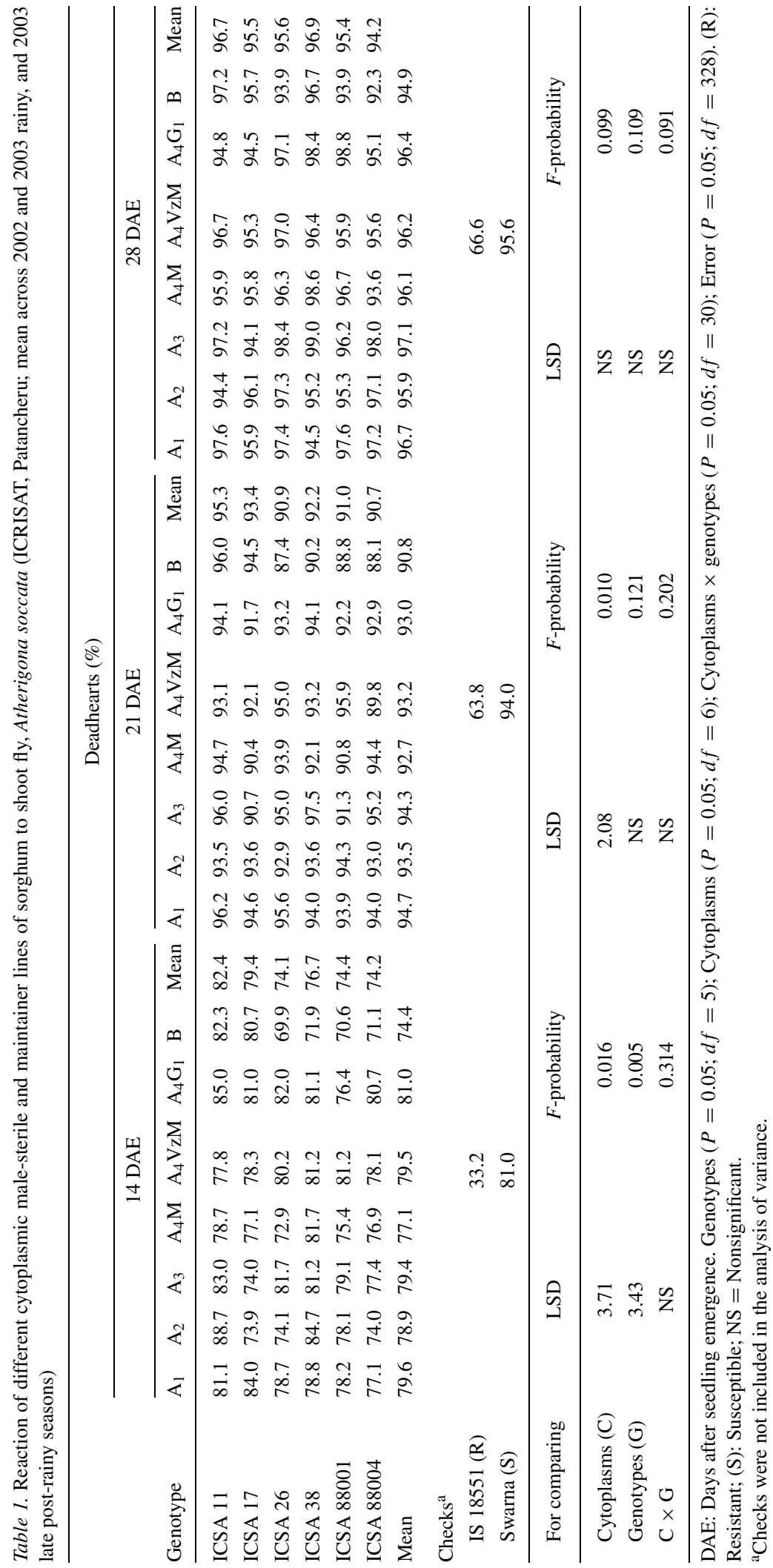


Table 2. Reaction of different cytoplasmic male-sterile and maintainer lines of sorghum to shoot fly, Atherigona soccata, under dual-choice conditions in the greenhouse (ICRISAT, Patancheru; rainy season 2003)

\begin{tabular}{|c|c|c|c|c|c|c|}
\hline \multirow[b]{2}{*}{ Genotype } & \multicolumn{2}{|c|}{ Seedlings with eggs (\%) } & \multirow[b]{2}{*}{$t$-value } & \multicolumn{2}{|c|}{ Deadhearts $(\%)$} & \multirow[b]{2}{*}{$t$-value } \\
\hline & A-line & B-line & & A-line & B-line & \\
\hline ICSA $11 \mathrm{~A}_{1}$ & 92.4 & 73.3 & $2.53^{*}$ & 84.6 & 61.2 & $2.86^{* *}$ \\
\hline ICSA $11 \mathrm{~A}_{2}$ & 100.0 & 94.4 & $2.22^{*}$ & 94.8 & 91.8 & 0.64 \\
\hline ICSA $11 \mathrm{~A}_{3}$ & 96.6 & 88.0 & 1.20 & 88.3 & 82.4 & 0.90 \\
\hline ICSA $11 \mathrm{~A}_{4} \mathrm{M}$ & 97.3 & 92.5 & 1.38 & 89.5 & 81.0 & 1.87 \\
\hline ICSA $11 \mathrm{~A}_{4} \mathrm{VzM}$ & 82.5 & 76.2 & 1.26 & 67.5 & 68.2 & 0.12 \\
\hline ICSA $11 \mathrm{~A}_{4} \mathrm{G}_{1}$ & 100.0 & 100.0 & $*$ & 100.0 & 94.7 & 1.51 \\
\hline ICSA $17 \mathrm{~A}_{1}$ & 84.7 & 87.5 & 0.95 & 74.5 & 77.5 & 0.64 \\
\hline ICSA $17 \mathrm{~A}_{2}$ & 80.0 & 67.5 & $3.10^{* *}$ & 77.5 & 57.5 & $4.30^{* *}$ \\
\hline ICSA $17 \mathrm{~A}_{3}$ & 89.5 & 97.5 & $2.33^{*}$ & 82.0 & 89.8 & 1.42 \\
\hline ICSA $17 \mathrm{~A}_{4} \mathrm{M}$ & 66.2 & 72.7 & 0.80 & 63.7 & 72.7 & 1.27 \\
\hline ICSA $17 \mathrm{~A}_{4} \mathrm{VzM}$ & 82.5 & 81.5 & 0.39 & 80.0 & 78.9 & 0.23 \\
\hline ICSA $17 \mathrm{~A}_{4} \mathrm{G}_{1}$ & 85.0 & 97.5 & $4.01^{* *}$ & 77.5 & 84.6 & 0.84 \\
\hline ICSA $26 \mathrm{~A}_{1}$ & 77.5 & 82.5 & 1.46 & 75.0 & 75.0 & 0.00 \\
\hline ICSA $26 \mathrm{~A}_{2}$ & 88.7 & 90.0 & 0.20 & 80.3 & 70.0 & 1.23 \\
\hline ICSA $26 \mathrm{~A}_{3}$ & 90.0 & 95.0 & 1.46 & 72.5 & 82.2 & 1.25 \\
\hline ICSA $26 \mathrm{~A}_{4} \mathrm{M}$ & 97.5 & 90.0 & 1.19 & 82.5 & 85.0 & 0.28 \\
\hline ICSA $26 \mathrm{~A}_{4} \mathrm{VzM}$ & 87.5 & 92.5 & 1.46 & 82.5 & 85.0 & 0.40 \\
\hline ICSA $26 \mathrm{~A}_{4} \mathrm{G}_{1}$ & 52.5 & 76.7 & $6.60^{* *}$ & 49.7 & 71.3 & $5.37^{* *}$ \\
\hline ICSA $38 \mathrm{~A}_{1}$ & 87.5 & 85.0 & 0.27 & 72.3 & 80.0 & 1.42 \\
\hline ICSA $38 \mathrm{~A}_{2}$ & 72.5 & 59.9 & 2.00 & 67.4 & 52.1 & 1.51 \\
\hline ICSA $38 \mathrm{~A}_{3}$ & 92.4 & 86.8 & $2.20^{*}$ & 87.4 & 71.6 & $2.23^{*}$ \\
\hline ICSA $38 \mathrm{~A}_{4} \mathrm{M}$ & 77.0 & 82.5 & 1.70 & 74.1 & 80.0 & $4.27^{* *}$ \\
\hline ICSA $38 \mathrm{~A}_{4} \mathrm{VzM}$ & 100.0 & 90.0 & 1.94 & 89.6 & 92.5 & 0.53 \\
\hline ICSA $38 \mathrm{~A}_{4} \mathrm{G}_{1}$ & 92.2 & 94.7 & 0.56 & 92.2 & 81.6 & 2.01 \\
\hline ICSA $88001 \mathrm{~A}_{1}$ & 96.6 & 86.9 & $2.94^{* *}$ & 90.6 & 81.8 & 1.12 \\
\hline ICSA $88001 \mathrm{~A}_{2}$ & 100.0 & 94.7 & $2.75^{* *}$ & 92.5 & 91.8 & 0.14 \\
\hline ICSA $88001 \mathrm{~A}_{3}$ & 87.5 & 95.0 & 1.46 & 85.0 & 95.0 & 1.94 \\
\hline ICSA $88001 \mathrm{~A}_{4} \mathrm{M}$ & 87.3 & 86.1 & 0.22 & 82.2 & 72.9 & 1.90 \\
\hline ICSA $88001 \mathrm{~A}_{4} \mathrm{VzM}$ & 82.5 & 87.7 & 0.93 & 75.0 & 79.8 & 0.69 \\
\hline ICSA $88001 \mathrm{~A}_{4} \mathrm{G}_{1}$ & 91.8 & 92.2 & 0.05 & 78.8 & 70.2 & 1.19 \\
\hline ICSA $88004 \mathrm{~A}_{1}$ & 87.5 & 82.5 & 1.48 & 80.0 & 72.2 & $5.12^{* *}$ \\
\hline ICSA $88004 \mathrm{~A}_{2}$ & 100.0 & 100.0 & $*$ & 84.4 & 91.9 & 1.27 \\
\hline ICSA $88004 \mathrm{~A}_{3}$ & 67.5 & 66.4 & 0.24 & 60.0 & 50.9 & $4.18^{* *}$ \\
\hline ICSA $88004 \mathrm{~A}_{4} \mathrm{M}$ & 90.0 & 97.5 & 1.37 & 80.0 & 79.4 & 0.11 \\
\hline ICSA $88004 \mathrm{~A}_{4} \mathrm{VzM}$ & 81.1 & 85.9 & 0.76 & 62.0 & 75.6 & 1.56 \\
\hline ICSA $88004 \mathrm{~A}_{4} \mathrm{G}_{1}$ & 77.5 & 80.0 & 1.43 & 62.5 & 77.4 & $3.11^{* *}$ \\
\hline Mean & 86.7 & 86.4 & 1.60 & 78.8 & 77.9 & 1.65 \\
\hline
\end{tabular}

${ }^{*},{ }^{* *} t$-value significant at $P=0.05$ and 0.01 , respectively.

$\mathrm{A}_{4} \mathrm{G}_{1} \mathrm{CMS}$ backgrounds had significantly lower number of plants with eggs than the respective maintainer lines. ICSA 11 in $\mathrm{A}_{1}$, ICSA 17 in $\mathrm{A}_{2}$, ICSA 26 in $\mathrm{A}_{4} \mathrm{G}_{1}$, and ICSA 88004 in $A_{1}$ and $A_{3}$ CMS backgrounds had significantly more deadhearts than the corresponding maintainer lines, while reverse was true in case of ICSA 38 in $\mathrm{A}_{4} \mathrm{M}$ and ICSA 88004 in $\mathrm{A}_{4} \mathrm{G}_{1}$. In dual-choice tests, CMS lines had more percentage of plants with eggs and deadhearts than the corresponding maintainer lines. 


\section{Recovery resistance}

Tiller deadhearts were lower on the maintainer than in the CMS lines. $A_{4} G_{1}$ and $A_{4} M$ had lower tiller deadhearts than the other male-sterile cytoplasms tested (Figure 1C). The recovery resistance in CMS lines in milo cytoplasm was similar to that of maintainer lines, while in case of other cytoplasms, the CMS lines showed better recovery than the maintainer lines. Recovery resistance of $\mathrm{A}_{4} \mathrm{M}, \mathrm{A}_{3}$ and $\mathrm{A}_{2}$ cytoplasms was better than the other cytoplasms tested (Figure 1D).

\section{Antibiosis}

The larval and pupal periods were comparatively longer on the $\mathrm{A}_{4} \mathrm{M}$ and $\mathrm{A}_{4} \mathrm{VzM}$ cytoplasms as compared to other cytoplasms tested (Table 3). Larval survival was lower on $\mathrm{A}_{3}(87.3 \%)$ and $\mathrm{A}_{4} \mathrm{G}_{1}(88.4 \%)$ cytoplasms, while the pupal mortality was greater on $\mathrm{A}_{2}(12.1 \%)$ and $\mathrm{A}_{4} \mathrm{VzM}(11.5 \%)$ cytoplasms as compared to other cytoplasms tested (5.7-10.5\%). Adult emergence was significantly lower on $\mathrm{A}_{2}$ and $\mathrm{A}_{4} \mathrm{VzM}$ cytoplasms than on the other cytoplasms tested. The pupal weights were comparatively lower on $\mathrm{A}_{4} \mathrm{M}$ and $\mathrm{A}_{4} \mathrm{VzM}$ male-sterile cytoplasms than on the other cytoplasms tested, including the B-cytoplasm. The female pupae were heavier than the male pupae. Fecundity was lower on the CMS lines than on the respective maintainer lines. It was lower on $A_{1}, A_{2}$ and $A_{3}$ cytoplasms than the other cytoplasms tested. Fecundity and antibiosis indices varied from 0.96 to 2.01 and 4.71 to 5.64 , respectively. Fecun- dity and antibiosis indices were lower on CMS lines as compared to the maintainer lines, but better on $\mathrm{A}_{4} \mathrm{M}$ than on other CMS cytoplasms tested.

\section{Discussion}

A number of genotypes for resistance to shoot fly have been identified earlier (Taneja \& Leuschner, 1985; Sharma et al., 1992, 2003). The isogenic lines converted into different CMS backgrounds were susceptible to shoot fly. Oviposition and deadheart incidence were greater on the CMS than on the maintainer lines under multi-choice conditions in the field, and dualand multi-choice tests in the greenhouse. Greater susceptibility of CMS lines than the corresponding maintainer lines has earlier been reported in case of sorghum midge (Stenodiplosis sorghicola Coquillett) (Sharma et al., 1994; Sharma, 2001), and to sorghum shoot fly, midge, shoot bugs (Peregrinus maidis Ashmead) and aphids (Melanaphis sacchari Zehnter) (Sharma et al., 2004). Fusarium sheath rot (Fusarium moniliforme Sheldon Emend Snyder \& Hansen) and Karnal smut (Tilletia barclayana Brefeld) diseases of rice have also been reported to be more severe on the CMS lines and hybrids, as compared to maintainers and restorers (Sharma et al., 1993). The Kansas male-sterility based CMS lines such as KSA 34 to KSA 39 and Combine Kafir based CMS lines are equally susceptible to greenbug, Schizaphis graminum (Rondani) (Ross \& Kofoid, 1979). The Texas (T) type of cytoplasmic male-sterility in maize has been shown to be more susceptible to

Table 3. Antibiosis effects of different male-sterile cytoplasms on sorghum shoot fly, Atherigona soccata, under greenhouse conditions (ICRISAT, Patancheru; rainy season 2003)

\begin{tabular}{|c|c|c|c|c|c|c|c|c|}
\hline \multirow[b]{2}{*}{ Parameter } & \multicolumn{8}{|c|}{ Cytoplasm } \\
\hline & $\mathrm{A}_{1}$ & $\mathrm{~A}_{2}$ & $\mathrm{~A}_{3}$ & $\mathrm{~A}_{4} \mathrm{M}$ & $\mathrm{A}_{4} \mathrm{VzM}$ & $\mathrm{A}_{4} \mathrm{G}_{1}$ & B & $\mathrm{SE} \pm$ \\
\hline Larval period (days) & $8.10 \mathrm{a}$ & $8.18 \mathrm{a}$ & $8.13 \mathrm{a}$ & $8.41 \mathrm{c}$ & $8.32 b$ & $8.13 \mathrm{a}$ & $8.13 \mathrm{a}$ & 0.05 \\
\hline Pupal period (days) & $7.93 \mathrm{a}$ & $8.00 \mathrm{~b}$ & $8.08 \mathrm{c}$ & $8.01 \mathrm{~b}$ & $8.22 \mathrm{~d}$ & $7.94 \mathrm{a}$ & $7.92 \mathrm{a}$ & 0.04 \\
\hline Larval survival (\%) & $90.37 \mathrm{de}$ & $89.96 \mathrm{~d}$ & $87.35 \mathrm{a}$ & $90.58 \mathrm{e}$ & $89.80 \mathrm{~cd}$ & $88.44 \mathrm{~b}$ & $89.37 \mathrm{c}$ & 0.43 \\
\hline Pupal mortality (\%) & $8.30 \mathrm{c}$ & $12.10 \mathrm{f}$ & $5.70 \mathrm{a}$ & $8.20 \mathrm{c}$ & $11.50 \mathrm{e}$ & $7.00 \mathrm{~b}$ & $10.50 \mathrm{~d}$ & 0.90 \\
\hline Adult emergence $(\%)$ & $82.91 \mathrm{~d}$ & $79.1 \mathrm{a}$ & $82.32 \mathrm{~cd}$ & $83.17 d$ & 79.54ab & $82.19 \mathrm{c}$ & $80.01 \mathrm{~b}$ & 0.65 \\
\hline Male pupal weight (mg pupa ${ }^{-1}$ ) & $4.88 \mathrm{f}$ & $4.54 \mathrm{e}$ & 4.46de & $4.18 b$ & $4.02 \mathrm{a}$ & $4.33 \mathrm{c}$ & $4.39 \mathrm{~cd}$ & 0.10 \\
\hline Female pupal weight $\left(\mathrm{mg} \mathrm{pupa}^{-1}\right)$ & $6.73 d$ & $6.67 \mathrm{~d}$ & $6.22 b$ & $6.07 \mathrm{a}$ & $6.01 \mathrm{a}$ & $6.72 d$ & $6.47 \mathrm{c}$ & 0.12 \\
\hline Fecundity female ${ }^{-1}$ & $123.50 \mathrm{a}$ & $122.10 \mathrm{a}$ & $121.80 \mathrm{a}$ & $138.20 \mathrm{c}$ & $134.00 \mathrm{~b}$ & $130.90 \mathrm{~b}$ & $144.60 \mathrm{~d}$ & 3.33 \\
\hline Fecundity index & $1.31 \mathrm{a}$ & $1.30 \mathrm{a}$ & $1.29 \mathrm{a}$ & $1.47 \mathrm{c}$ & $1.42 \mathrm{~b}$ & $1.39 b$ & $1.54 \mathrm{~d}$ & 0.04 \\
\hline Antibiosis index & $5.14 \mathrm{c}$ & $5.02 \mathrm{a}$ & $5.01 \mathrm{a}$ & $5.16 \mathrm{~d}$ & $5.04 \mathrm{~b}$ & $5.14 \mathrm{c}$ & $5.22 \mathrm{e}$ & 0.01 \\
\hline
\end{tabular}

Means followed by different letters in a row are significantly different at $P=0.05$ (ANOVA). The mean values for each cytoplasm are based on insect survival per 45 larvae genotype ${ }^{-1}$ in six CMS backgrounds. 
fungal toxins than the normal fertile plants, and those with other types of CMS system (Fed' ko et al., 1989). Yadav (1996) reported that $\mathrm{A}_{2}, \mathrm{~A}_{3}$ and $\mathrm{A}_{4}$ cytoplasms in pearl millet were less susceptible to downy mildew, and they can be exploited to broaden the cytoplasmic base of the CMS lines for hybrid production. The hybrids based on $\mathrm{A}_{2}, \mathrm{~A}_{3}$ and Violaceum cytoplasms showed better resistance to downy mildew, ergot and smut than the $A_{1}$ cytoplasm (Mangat et al., 1996).

Antibiosis to shoot fly offers exciting possibilities of exerting constant pressure against larvae, resulting in low larval survival on resistant varieties (Dahms, 1969; Soto, 1974). Retardation of growth and development, prolonged larval and pupal periods, and poor emergence of adults on resistant varieties provides direct evidence of antibiosis (Singh \& Jotwani, 1980; Raina et al., 1981). The larval and pupal stages are completed in 8 to 10 days each and the total life cycle from egg to adult varied from 17 to 21 days (Kundu \& Kishore, 1970; Zein el Abdin, 1981). Longer larval, pupal and total developmental periods, and lower male and female pupal weights on $\mathrm{A}_{4} \mathrm{M}$ and $\mathrm{A}_{4} \mathrm{VzM}$ cytoplasms compared to other CMS systems indicated the presence of antibiosis against the sorghum shoot fly in these cytoplasms. The mortality was comparatively greater on $\mathrm{A}_{3}(12.7 \%)$ cytoplasm during the larval stage, and $\mathrm{A}_{2}$ (12.1\%) and $\mathrm{A}_{4} \mathrm{VzM}(11.5 \%)$ cytoplasms during the pupal stage. The shoot fly fecundity was greater on the susceptible variety, Swarna than on moderately resistant varieties, IS 2123 and IS 5604 (Singh \& Narayana, 1978). The females reared on $\mathrm{A}_{4} \mathrm{M}$ cytoplasm laid more number of eggs than other cytoplasms. There is considerable variability in fecundity (17-239 eggs female ${ }^{-1}$ ) of sorghum shoot fly females (Ogwaro, 1978; Meksongsee et al., 1978, 1981; Raina, 1982). Keeping in view the past and present observations, there is a need for partitioning antibiosis component under controlled conditions.

Recovery resistance has been reported to be partially related to tillering response to shoot fly damage (Doggett et al., 1970), level of primary resistance, and productive tillers (Sharma et al., 1977). $\mathrm{A}_{4} \mathrm{M}$ and $\mathrm{A}_{4} \mathrm{G}_{1}$ cytoplasms had significantly less tiller deadhearts, while $\mathrm{A}_{2}, \mathrm{~A}_{3}$ and $\mathrm{A}_{4} \mathrm{M}$ cytoplasms showed better recovery resistance than the other CMS cytoplasms. These can be exploited for producing sorghum hybrids with low susceptibility to sorghum shoot fly. The hybrids based on maldandi $\left(\mathrm{A}_{4} \mathrm{M}\right)$ cytoplasm have longer grains and higher grain yield than those based on milo cytoplasm (Gangakishan \& Borikar, 1989; Wang et al., 1990). The $A_{4} M$ (maldandi) cytoplasm was also found to be less susceptible to sorghum shoot fly, showed good recovery resistance, and higher antibiosis index than the milo cytoplasm, and thus can be exploited for developing shoot fly-resistant hybrids. The shoot flyresistant lines may be converted into $\mathrm{A}_{4} \mathrm{MCMS}$ system, which in combination with shoot fly-resistant restorers can be used to produce sorghum hybrids with high levels of resistance to this pest.

\section{Acknowledgments}

We thank Dr. B.U. Singh, Principal Scientist, Entomology, National Center for Sorghum Research (NRCS), Rajendranagar, Hyderabad, Andhra Pradesh, India for his critical comments on the manuscript, the ICRISAT entomology staff, Messrs G. Pampapathy, V. Venkateshwara Rao, J. Raja Rao, V. Madhusudhan Reddy, K. Hareendranath, S.V.N. Chandra and Mrs. Ponnamma for their help in these experiments. Suri Sehgal Foundation Funds financially supported these studies.

\section{References}

Dahms, R.G., 1969. Theoretical effects of antibiosis on insect population dynamics. USDA, ERO, Beltsville, Maryland, USA, 5 pp. Deeming, J.C., 1971. Some species of Atherigona Rondani (Diptera: Muscidae) from northern Nigeria, with special reference to those injurious to cereal crops. Bull Entomol Res 61: 133-190.

Deshmukh, P.D., Y.S. Rathore \& A.K. Bhatacharaya, 1977. Studies on growth and development of Diacrisia obliqua Walker on sixteen plant species. Z Angew Ent 84: 431-455.

Dhillon, M.K., 2004. Effects of cytoplasmic male-sterility on expression of resistance to sorghum shoot fly, Atherigona soccata (Rondani). Ph.D. Thesis, Department of Entomology, Chaudhary Charan Singh Haryana Agricultural University, Hisar, Haryana, India, $382 \mathrm{pp}$.

Doggett, H., K.J. Starks \& S.A. Eberhart, 1970. Breeding for resistance to the sorghum shoot fly. Crop Sci 10: 528-531.

FAO, 2002. Year Book 56. Food and Agriculture Organization, Rome, Italy.

Fed' ko, I.A., B.A. Tereshchenko \& A.A. Morshatskii, 1989. Specific effect of T toxin and its use in studies. Selektsiya i Semenovodstvo Moskva 6: 18-20.

Gangakishan, A. \& S.T. Borikar, 1989. Comparative performance of Maldandi V/S Milo cytoplasm in sorghum. J Maharashtra Agric Univ 14: 192-195.

Hiremath, P.S. \& M.K. Renukarya, 1966. Occurrence, distribution and abundance of shoot fly on CSH 1. Sorghum Newslett 9: 37.

House, L.R., 1985. A Guide to Sorghum Breeding. International Crops Research Institute for the Semi-Arid Tropics, Patancheru, Andhra Pradesh, India, pp. 83-84.

Howe, R.W., 1971. A parameter for expressing suitability of an environment for insect development. J Stored Prod Res 7: 63-65. 
Kundu, G.G. \& P. Kishore, 1970. Biology of the sorghum shoot fly, Atherigona varia soccata Rond. (Diptera: Anthomyiidae). Indian J Entomol 32: 215-217.

Mangat, B.K., H.S. Randhawa \& D.S. Virk, 1996. Grain yield potential and disease reaction of diverse pearl millet hybrids. Crop Improvement 23: 99-104.

Meksongsee, B., M. Chawanapong, U. Sangkasuwan \& P. Poonyathaworn, 1981. The biology and control of the sorghum shoot fly, Atherigona soccata Rondani, in Thailand. Insect Sci Appl 2: $111-116$.

Meksongsee, B., A. Kongkanjana, U. Sangkasuwan \& W.R. Young, 1978. Longevity and oviposition of sorghum shoot fly adults on different diets. Ann Entomol Soc Am 71: 852-853.

Nagur, T., 1971. Studies on fertility restoration and combining ability in relation to genetic diversity and cytoplasmic constitution in sorghum. Ph.D. Thesis, Tamil Nadu Agricultural University, Coimbatore, Tamil Nadu, India.

Ogwaro, K., 1978. Observations on longevity and fecundity of the sorghum shoot fly, Atherigona soccata (Diptera: Anthomyiidae). Entomol Exp Appl 23: 131-138.

Pont, A.C., 1972. A review of the Oriental species of Atherigona Rondani (Diptera: Muscidae) of economic importance. In: M.G. Jotwani \& W.R. Young (eds.), Control of Sorghum Shoot fly, Oxford \& IBH Publishing Co., New Delhi, India, pp. 27-104.

Prasad, J. \& A.K. Bhattacharaya, 1975. Growth and development of Spodoptera littoralis (Boisd.) on several plants. Z Angew Ent 79: $34-48$.

Raina, A.K., 1982. Fecundity and oviposition behavior of the sorghum shoot fly, Atherigona soccata. Entomol Exp Appl 31: 381-385.

Raina, A.K., H.Z. Thindwa, S.M. Othieno \& R.T. Corkhill, 1981. Resistance in sorghum to sorghum shoot fly: Larval development and adult longevity and fecundity on selected cultivars. Insect Sci Appl 2: 99-103.

Rao, M. \& S. Gowda, 1967. A short note on the bionomics and control of jowar fly. Sorghum Newslett 10: 55-57.

Reddy, B.V.S. \& P. Rao, 1998. Diversification of sorghum malesterile lines at ICRISAT. In: C.L.L. Gowda \& J.W. Stenhouse (eds.), Strengthening Sorghum Research Collaboration in Asia. Report of the Asian Sorghum Scientists' Meeting, 18-21 November 1997, Suphan Buri, Thailand: International Crops Research Institute for the Semi-Arid Tropics, Patancheru, Andhra Pradesh, India, pp. 13-16.

Ross, W.M. \& K.D. Kofoid, 1979. Effect of non-milo cytoplasms on the agronomic performance of sorghum. Crop Sci 19: 267-270.

Saxena, K.N., 1969. Patterns of insect-plant relationship determining susceptibility or resistance of different plants to an insect. Entomol Exp Appl 12: 751-766.

Schertz, K.F. \& D.R. Pring, 1982. Cytoplasmic male sterility systems in sorghum. In: L.R. House, L.K. Mughogho \& J.M. Peacock (eds.), Sorghum in the Eighties, International Crops Research Institute for the Semi-Arid Tropics, Patancheru, Andhra Pradesh, India, pp. 373-383.

Schertz, K.F., S. Sivaramakrishnan, W.W. Hanna, J. Mullet, Y. Sun, U.R. Murty, D.R. Pring, K.N. Rai \& B.V.S. Reddy, 1997. Alternate cytoplasms and apomixis of sorghum and pearl millet. In: Proceedings of the International Conference on Genetic Improvement of Sorghum and Pearl Millet, 22-27 September 1996, Lubbock, Texas, USA, pp. 213-223.

Schertz, K.F., R.A. Sotomayor \& C. Torres, 1989. Cytoplasmic male sterility-opportunities in breeding and genetics. In: F. Hang (ed.),
Proceedings of the 16th Biennial Grain Sorghum Research Utility Conference, Lubbock, Texas, USA, pp. 175-186.

Sharma, G.C., M.G. Jotwani, B.S. Rana \& N.G.P. Rao, 1977. Resistance to the sorghum shoot fly, Atherigona soccata (Rond.) and its genetic analysis. J Entomol Res 1: 1-12.

Sharma, H.C., 2001. Cytoplasmic male-sterility and source of pollen influence the expression of resistance to sorghum midge, Stenodiplosis sorghicola. Euphytica 122: 391-395.

Sharma, H.C., M.K. Dhillon, J.S. Naresh, Ram Singh, G. Pampapathy \& B.V.S. Reddy, 2004. Influence of cytoplasmic male-sterility on the expression of resistance to insects in sorghum. In: T. Fisher, N. Turner, J. Angus, L. McIntyre, M. Robertson, A. Borrell \& D. Llyod (eds.), Proceedings of the Fourth International Crop Science Congress, 25 September-1 October 2004, Brisbane, Australia.

Sharma, H.C., S.L. Taneja, N. Kameswara Rao \& K.E. Prasada Rao, 2003. Evaluation of sorghum germplasm for resistance to insect pests. Information Bulletin No. 63. International Crops Research Institute for the Semi-Arid Tropics, Patancheru, Andhra Pradesh, India, $177 \mathrm{pp}$.

Sharma, H.C., S.L. Taneja, K. Leuschner \& K.F. Nwanze, 1992. Techniques to screen sorghum for resistance to insect pests. Information Bulletin No.32, International Crops Research Institute for the Semi-Arid Tropics, Patancheru, Andhra Pradesh, India, 48 pp.

Sharma, H.C., P. Vidyasagar, C.V. Abraham \& K.F. Nwanze, 1994. Effect of cytoplasmic male-sterility in sorghum on host plant interaction with sorghum midge, Contarinia sorghicola. Euphytica 74: 35-39.

Sharma, R.C., G.S. Sidhu, T.S. Bharaj \& H.L. Sharma, 1993. Pathological constraints on hybrid rice production technology. Int Rice Res Notes 18: 15.

Singh, S.P. \& M.G. Jotwani, 1980. Mechanism of resistance in sorghum to shoot fly II. Antibiosis. Indian J Entomol 42: 240247.

Singh, R. \& K.L. Narayana, 1978. Influence of different varieties of sorghum on the biology of sorghum shoot fly. Indian J Agric Sci 48: 8-12.

Soto, P.E., 1974. Ovipositional preference and antibiosis in relation to resistance to sorghum shoot fly. J Econ Entomol 67: 265267.

Taneja, S.L. \& K. Leuschner, 1985. Resistance screening and mechanisms of resistance in sorghum to shoot fly. In: Proceedings of the International Sorghum Entomology Workshop, 15-21 July, 1984, Texas A\&M University, College Station, Texas, USA; International Crops Research Institute for the Semi-Arid Tropics, Patancheru, Andhra Pradesh, India, pp. 115-129.

Tripathi, A.K., A.K. Bhattacharaya \& S.K. Verma, 1982. Developmental behavior of Mythimna separata (Walker) on some monocotyledonous plants. Indian J Entomol 44: 355-367.

Wang, F.D., S.P. Zhang \& L.G. Yang, 1990. Evaluation of A2 malesterile lines in sorghum II. Combining ability analysis for main agronomic characters. Acta Agron Sinica 16: 242-251.

Xu, Z.G.T., F.M. Kong, X.P. Shen \& M. Cheng, 1998. Forecasting of resistance to bacterial blight in indica hybrid rice and its parents. J Southwest Agric Univ 20: 409-413.

Yadav, O.P., 1996. Downy mildew incidence of pearl millet hybrids with different male-sterility inducing cytoplasms. Theor Appl Genet 92: 278-280.

Zein el Abdin, A.M., 1981. Review of sorghum shoot fly research in the Sudan. Insect Sci Appl 2: 55-58. 